\title{
Contribuições da racionalidade comunicativa, racionalidade substantiva e ambiental para os estudos organizacionais
}

\author{
Contributions of communicative, substantive and environmental rationality to \\ organizational studies
}

\author{
Valdir Fernandes ${ }^{1}$ \\ Osmar Ponchirolli ${ }^{2}$
}

\section{Resumo}

O tema deste artigo insere-se nos estudos da teoria organizacional e racionalidade. Traz análise acerca dos ensaios sobre racionalidade substantiva de Guerreiro Ramos, racionalidade ambiental de Enrique Leff e visão Habermasiana de Ação Comunicativa e suas implicações no universo organizacional. O método que caracteriza este artigo é a revisão bibliográfica, com utilização de fontes múltiplas de evidência. Os dados foram obtidos mediante investigação bibliográfica, e a análise dos dados foi efetuada de forma descritivo-interpretativa. Utilizaram-se, para tanto, análise de conteúdo e a análise documental. Dentre as conclusões baseadas nas proposições desses autores, está a possibilidade de uma perspectiva crítica capaz de identificar e de enfrentar as patologias que o mundo atual exige, com ênfase para os parâmetros da razão comunicativa. É esta razão que deve controlar, em última instância, os processos sistêmicos, colocando-os a serviço das finalidades humanas comunicativamente estabelecidas. $\mathrm{Na}$ análise das proposições desses três autores, a discussão que emerge é que o tipo de racionalidade presente na ação social depende essencialmente da motivação da ação, o que necessariamente deve ser incorporado pela teoria organizacional.

Palavras-chave: Racionalidade comunicativa. Racionalidade substantiva. Racionalidade ambiental. Teoria organizacional.

\begin{abstract}
The theme of this article falls within organizational and rationality theory. It presents an analysis of essays concerning the substantive rationality of Guerreiro Ramos, the environmental rationality of Enrique Leff, the Habermasian vision of Communicative Action and their implications in the organizational universe. The article's methodology is based on a bibliographic review of multiple sources. The data were obtained through bibliographic research, and the data analysis was conducted in a descriptive-interpretive manner. For this purpose, content and document analyses were used. The

Artigo submetido em 03 de julho de 2010 e aceito para publicação em 25 de março de 2011.

1

Cientista Social e Doutor em Engenharia Ambiental; Professor do Programa de Pós-Graduação em Organizações e Desenvolvimento da FAE - Centro Universitário. Endereço: Rua 24 de Maio, 135, Centro, CEP 80230-080, Curitiba/PR, Brasil. E-mail: valdir.fernandes@live.fae.edu

${ }^{2}$ Filósofo e Doutor em Engenharia de Produção; Professor do Programa de Pós-Graduação em Organizações e Desenvolvimento da FAE - Centro Universitário. Endereço: Rua 24 de Maio, 135, Centro, CEP 80230-080, Curitiba/PR, Brasil. E-mail: osmarp@bomjesus.br
\end{abstract}


conclusions based on the proposals of these authors include the possibility of a critical perspective capable of identifying and confronting the pathologies that the current world demands, with an emphasis on the parameter of communicative reason. In the final instance, this should control the systematic processes, placing them at the service of the communicatively established human ends. In the analysis of the proposals of these three authors, the discussion that emerges is that the type of rationality found in social action depends essentially on the motivation of action that must necessarily be incorporated into organizational theory.

Keywords: Communicative rationality. Substantive rationality. Environmental rationality. Organizational theory.

\section{Introdução}

Não obstante a consagração da sociedade ocidental como uma sociedade que se desenvolveu profundamente baseada nos critérios da racionalidade instrumental, recheada de racionalidade econômica e de economia formal (não necessariamente nessa ordem), tem havido tentativas de expandir conceitos que resgatam a economia no seu sentido substantivo. No universo destes conceitos, principalmente da teoria organizacional, merecem destaque três autores, cujas propostas de racionalidade são provocativas: Habermas (1981, 1990, 1991, 1992, 1993), Ramos (1989, 2001) e Leff (1986, 1993, 2001). Segundo Habermas (1987), o pensamento grego não buscava nem uma teologia nem uma cosmogonia ética, como o faziam os grandes sistemas religiosos, e sim uma espécie de ontologia. A filosofia, desde a Grécia antiga, vinha tentando estabelecer explicações do mundo utilizando-se de princípios centrados na razão. Nesse sentido, a razão seria o tema fundamental da filosofia.

Habermas crê num padrão emergente nas relações entre a filosofia e a ciência, ocasionadas pelo fracasso dos intentos de fundamentação última da Filosofia Primeira (HABERMAS, 1987). Tal argumentação foi desenvolvida na direção de que as teorias sobre as ciências experimentais modernas não poderiam mais ser respaldadas por pressupostos fundamentalistas, sejam do tipo ontológico ou do tipo transcendental.

Tanto a sociologia como a antropologia cultural se veem confrontadas com o espectro completo dos fenômenos da ação social e não com tipos de ação relativamente bem delimitados que possam ser interpretados como variantes da ação 'racional com respeito a fins, relativas aos problemas de maximização do lucro ou da aquisição e utilização do poder político. Essas duas disciplinas se ocupam da prática cotidiana nos contextos do mundo da vida e têm, portanto, que levar em consideração todas as formas de orientação simbólica da ação (HABERMAS, 1987, p. 21).

No campo da administração, segundo Guerreiro Ramos, a teoria corrente dá um cunho normativo geral ao desenho implícito na racionalidade funcional (GUERREIRO RAMOS, 1981, p. 23).

$\mathrm{Na}$ concepção de Habermas (1996), essas proposições não devem ser analisadas como tentativas de construir um conceito sem reflexo no mundo-da-vida, mas, como esforço de resgatar dimensões menos valorizadas e menos evidenciadas na dinâmica social-produtiva e na teoria social.

Ramos (1989), inspirado na Escola de Frankfurt e pensando em termos de teoria organizacional, resgata o conceito de racionalidade aristotélico e referente a valores de Max Weber, a partir dos quais propõe um conceito de racionalidade substantiva, que acredita ser mais sadio que o conceito de racionalidade instrumental predominante na teoria organizacional vigente. Vale ressaltar que todo o pensamento de Ramos é construído no contexto da Teoria das Organizações e deve ser analisado e compreendido sob esta perspectiva. 
Leff, por sua vez, propõe o conceito de racionalidade ambiental como uma forma de incluir esse aspecto nas análises da ação social produtiva, alinhado ao pensamento complexo e à epistemologia ambiental.

A pertinência da análise desses três ensaios consiste no fato de que no primeiro, Habermas, identifica que, na análise da racionalização do social, Weber se deixa levar unicamente pelo conceito de racionalidade enquanto razão com respeito a fins. Assim, Weber teria concentrado toda a essência de sua proposição na redução do que chamou de racionalização do social ao aumento da racionalidade instrumental nos contextos da ação.

Habermas (1980, p. 199) afirma categoricamente que a racionalização das orientações de ação e das estruturas do mundo da vida não é o mesmo que o aumento de complexidade dos sistemas de ação.

Percebe-se a importância da tese de Weber nas formulações de Habermas sobre a racionalidade. Habermas inicia a sua própria construção teórica:

Para dar uma nova formulação teórica àquilo que Max Weber chamou de 'racionalização', gostaria de não me ater ao ponto de partida subjetivo que Parsons compartilha com Weber, e de propor um outro quadro categorial. Partirei da distinção entre trabalho e interação. Entendo por 'trabalho', ou agir racional com respeito a fins, seja o agir instrumental, seja a escolha racional, seja a combinação dos dois. [...] Por outro lado, entendo por agir comunicativo uma interação mediatizada simbolicamente. Ela se rege por normas que valem obrigatoriamente, que definem as expectativas de comportamento recíprocas e que precisam ser compreendidas e reconhecidas por, pelo menos, dois sujeitos agentes. [...] Dispondo desses dois tipos de ação, podemos classificar os sistemas sociais conforme neles predomine o agir racional com respeito a fins ou a interação (HABERMAS, 1980, p. 320321).

A opção de Habermas em trabalhar com outra modalidade de racionalidade, alternativa à razão instrumental, é evidente na reconceituação dos tipos de ação. Desse modo, ele inicia a elaboração da sua Teoria da Ação Comunicativa.

O segundo, de Ramos (1989), é uma tentativa de resgate daquela dimensão racional que dá o caráter de reflexão crítica e julgamento ético e político e que foi sucumbida pelo processo formalizante da economia de mercado e da racionalidade instrumental, que, em termos metodológicos, é categoria de análise fundamental para a análise social e organizacional. O terceiro ensaio, formulado por Leff (2001), toca em um ponto nevrálgico do processo de desenvolvimento e civilizatório. A partir da problemática ambiental, trata da inserção dessa dimensão como critério de racionalidade, e, portanto (vírgula) de decisão com interfaces ora instrumental, ora substantiva.

Torna-se necessário esclarecer também, que o objetivo deste ensaio não é fazer qualquer comparação entre as concepções ou nível de aprofundamento, mas trabalhá-las como complementares. O conceito weberiano de "racionalidade referente a valores" e de "racionalidade referente a fins" que é diferente daquilo que Habermas considera racionalidade da ação comunicativa, bem como diferente daquilo que, Guerreiro Ramos e Leff, consideram racionalidade substantiva e racionalidade ambiental respectivamente. Portanto, não se devem confundir os conceitos propostos por Habermas, Ramos e Leff com as tipologias "racionalidade de valor" e "racionalidade referente a fins" de Weber. São proposições que vão além da proposição weberiana.

Para Weber, no processo de modernização, há um agir racional que tem em vista fins, do qual decorre a burocratização e a coisificação das relações sociais. Habermas, porém, mostra outras dimensões sociais e outros tipos de racionalidade, que atendem aos aspectos prático-morais e estético-expressivos, dos quais a Teoria da Ação Comunicativa é essencial. Habermas critica a filosofia analítica que restringe a linguagem à proposição com valor de verdade e assim reduz a linguagem à função referencial. Não se trata apenas da constatação através de asserções, mas é importante a ação entre entendimento linguístico que gera interações 
entre sujeitos linguística e interativamente competentes mediadas por atos de entendimento. Além do aspecto sintático e do conteúdo semântico definido pela referência a objetos ou estados de coisas, que geram a função expositiva, existem, também aspectos pragmáticos, relacionados aos contextos e à situação de fala.

A racionalidade comunicativa se constituiria precisamente a partir dos pressupostos da interação e da linguagem. Sua função seria a de possibilitar o entendimento entre os indivíduos, a negociação de seus interesses e objetivos e a formação do consenso na sociedade.

Habermas acusa Weber de partir de um conceito de ação "estruturado monologicamente". Weber não tem como pano de fundo uma teoria do significado, e sim uma teoria intencionalista da consciência. Como Weber partiu de um conceito de ação estruturado monologicamente, ele não pode desenvolver o conceito de "ação social" através da via da explicação do sentido. Habermas declara-se plenamente convencido de que Weber partiu de um modelo teleológico de ação e não de um modelo de interação social. Um acordo alcançado por meio de ações comunicativas tem que ter uma base racional. Habermas amplia a possibilidade da racionalidade de uma ação; ele parte de um ponto de vista interativo, agregando variáveis inteiramente novas à proposição de Weber, sem negar o aspecto teleológico da ação comunicativa. Propõe encontrar os fundamentos de uma teoria crítica da sociedade na linguagem enquanto comunicação, isto é, enquanto mediadora das relações sociais. A pragmática se insere no quadro mais amplo de uma filosofia crítica que tem um objeto emancipatório e está voltada para a recuperação, em nosso contexto histórico, do lugar central da racionalidade comunicativa.

Ramos, também partido de Weber, resgata a noção aristotélica de Razão para propor uma noção de racionalidade substantiva como capacidade de reflexão individual e coletiva que, com o predomínio da racionalidade instrumental e o automatismo, perdeu espaço nos processos de tomada de decisão e análise, principalmente no âmbito organizacional.

A racionalidade substantiva não pode ser resumida à crença em valores, que inclusive Weber demonstrou em "A Ética Protestante e o Espírito do Capitalismo" ser em alguns casos altamente instrumental e não substantiva. A noção de uma racionalidade substantiva está muito mais ligada a um processo de emancipação política do ser humano enquanto indivíduo, que não delega ao grupo social o seu poder de decisão. Ramos sugere que, fundamentada na racionalidade instrumental, a vida organizacional e social tira do indivíduo a sua capacidade de reflexão, remetendo-lhe a um processo de automatismo. O processo de racionalização da vida que levou o indivíduo e a sociedade ao processo de automatismo e de diminuição da capacidade de reflexão, que a rigor é a capacidade política de ponderar critérios, não apenas baseados nas noções de mais (+) e de menos (-), como criticado por Gorz (2003), mas nas noções de suficiente (FERNANDES, 2008).

Leff, por sua vez, baseia-se fortemente em ambas as tipologias de racionalidade, de valor e instrumental, para propor o que denomina "racionalidade ambiental". Segundo o entendimento do próprio autor, não se trata de uma variação ou evolução da racionalidade de valor weberiana ou mesmo da racionalidade substantiva. A deflagração de um conjunto de novos problemas no mundo contemporâneo, com destaque para a crise ambiental, remete a humanidade para uma reflexão que não pode ser realizada apenas ponderando os critérios da racionalidade instrumental, tampouco desconsiderá-los. O que Leff almeja, ao propor a noção de racionalidade ambiental, é que outros critérios sejam considerados na reflexão, dentre os quais os ambientais.

\section{Racionalidade da ação Comunicativa em Habermas}

A reflexão do Filósofo alemão Jürgen Habermas, herdeiro da Escola de Frankfurt, desenvolve uma teoria crítica da sociedade contemporânea a partir de uma crítica dos modos de racionalidade nela impregnados. 
Na década de 70, Habermas recorre ao pensamento de Weber, Mead e Piaget para reconstruir o materialismo histórico. Sua atenção volta-se para filósofos como Wittgenstein, Austin, Searle e Grice. É exatamente a visão pragmática de linguagem, enfatizando a comunicação e a ação, que lhe interessa nesses filósofos. Habermas vai buscar na Hermenêutica de Hans Georg Gadamer, a valorização do significado quanto da tradição na transmissão da linguagem.

Habermas propõe-se a encontrar os fundamentos de uma teoria crítica da sociedade na linguagem, enquanto comunicação, isto é, enquanto mediadora das relações sociais. Neste sentido, é mister analisar pragmaticamente a linguagem, além de uma consideração meramente empírica dos usos concretos. É esse o sentido da proposta da Pragmática Universal, primeiro passo em direção à Teoria da Ação Comunicativa, que visa estabelecer as condições de possibilidade da comunicação, em um sentido universal.

Habermas destaca dois fatores determinantes em toda sociedade: o trabalho e a interação. Além do trabalho, o paradigma da interação social orientada por sujeitos em sua ação integradora é fruto da evolução social e individual. Na Modernidade, com a racionalização e a tecnicização das relações sociais, acentua-se a distinção entre trabalho e interação. A interação comunicativa é caracterizada como tendo uma natureza essencialmente cooperativa e define quatro condições do que denomina situação de discurso: sinceridade, inteligibilidade e justificabilidade.

A pragmática tem um objetivo emancipatório e está voltada para a recuperação, em nosso contexto histórico, do lugar central da racionalidade comunicativa.

Para Habermas, "não é propriamente a razão que está em crise, mas uma forma atrofiada e reducionista de razão que se fez dominante nos últimos séculos". (OLIVEIRA, 1990, p.81-82). Busca resgatar o potencial de criticidade por meio da elaboração de uma teoria ampla da racionalidade.

O projeto iluminista ainda não esgotou suas possibilidades, segundo Habermas. A ideia de libertação, isto é, de sua emancipação, teria um duplo sentido: dominar as forças da natureza, colocando-as a seu serviço, e superar as escravidões que os homens mutuamente se impuseram, especialmente pela força dos dogmas, das crenças e das ideologias. Os homens obtiveram um grande domínio tecnológico sobre a natureza, mas não souberam encaminhar devidamente os problemas da convivência da ética e da justiça social; a razão técnicoinstrumental floresceu e subjugou a razão prática (ROUANET, 1987, p.341ss).

Habermas identifica na raiz desse processo a concepção positivista de ciência que, exaltando as questões dos valores, da ética e da justiça para o âmbito da "irracionalidade" científica. A alternativa que Habermas encontra é a da construção de uma teoria ampla da racionalidade, capaz de submeter à crítica a concepção positivista, bem como dar conta das questões políticas da convivência humana.

A mudança de Paradigma que Habermas propõe é a de que o parâmetro da racionalidade de crítica deixa de ser o sujeito cognoscente que se relaciona com os objetos a fim de conhecê-los e manipulá-los, passando a ser a relação intersubjetiva que os sujeitos entre si estabelecem a fim de se entenderem sobre algo (HABERMAS, 1992 I, p.499).

O interesse de Habermas é elaborar uma teoria da racionalidade que contemple, além do elemento cognitivoinstrumental, o elemento prático-moral e o elemento estético-expressivo (HABERMAS, 1990b, p.291).

Não houve apenas um avanço da razão instrumental sobre os âmbitos indefinidos, mas uma assimilação desta, como única forma de racionalidade possível. Habermas se propõe resgatar o potencial de racionalidade que emerge de contextos interativos, tal resgate consiste na reconstrução racional do agir comunicativo.

A teoria da ação comunicativa se propõe a "investigar a razão inscrita na própria prática comunicativa cotidiana e reconstruir a partir da base de validez da fala um conceito não reduzido de razão". (HABERMAS, 1989a, p.506) baseada num reducionismo empírico-instrumental, tem-se arvorado dono da racionalidade. 
A racionalidade comunicativa mostra-se atuante no processo de reprodução da sociedade sob o ponto de vista de suas estruturas simbólicas: as tradições culturais, as solidariedades sociais e as identidades pessoais. Com isso o conceito de agir comunicativo torna-se importante. Reprodução no sentido de integração social operada por meio da reprodução simbólica do mundo da vida.

Habermas propõe em sua teoria crítica que se compreenda a sociedade como unidade constituída de sistema e mundo de vida, contemplando ao mesmo tempo os domínios da razão instrumental e da razão comunicativa. A percepção adequada dos complexos problemas de reprodução da sociedade estaria condicionada, assim, à devida consideração desses dois domínios de racionalidade e das relações que se estabelecem entre as duas formas de interação: a social, mediada por um consenso normativo, e a sistêmica, baseada em conexões funcionais.

A possibilidade de uma perspectiva crítica capaz de identificar e de enfrentar as patologias do mundo atual exige, em todo caso, o parâmetro da razão comunicativa. É esta que deve controlar, em última instância, os processos sistêmicos, colocando-os a serviço das finalidades humanas comunicativamente estabelecidas. A ordem do dia consiste em preservar e ampliar os espaços nos quais a razão comunicativa pode ser cultivada, delimitando-se claramente os espaços de atuação da razão instrumental. (FREITAG, 1993, p.62).

As evidências quanto à possível fecundidade da reflexão habermasiana para a economia se deve à constatação de que os objetivos gerais da economia se colocam na perspectiva de transformar os recursos em bens e serviços para suprir as necessidades das pessoas.

No final do século XX, a filosofia registra o fato auspicioso da extraordinária ascensão da Ética. O debate ético, hoje, está ao alcance de todos os interessados na discussão de problemas morais. A ética ao alcance de todos renasce. Seu desafio é encontrar um ponto de partida novo, abrangente e capaz de interpretar o homem, a terra, e o universo nas suas novas circunstâncias.

Entramos na fase da política Global em matéria de saúde, educação, economia, tecnologia e ecologia. Uma das questões centrais é trazer à tona a discussão em relação da motivação da ação. Qual a importância da teoria do agir comunicativo para compreendermos o valor da motivação da ação neste início de século?

A Teoria do Agir Comunicativo é um dos paradigmas nesta virada de milênio. De raiz Kantiana, a teoria da Ética Comunicativa, é liderada por Otto Apel e J. Habermas. Para estes autores, a compatibilizacão do exercício público da liberdade não se faz pela lei, mas pelo diálogo, como lugar da invenção ética.

Inventar a ética não é mero exercício da imaginação, mas esforço para descobrir o princípio mais adequado para responder, da melhor maneira possível, a um problema ético determinado.

O tema central da Teoria do Agir comunicativo é o paradigma da comunicação, da intersubjetividade, da ação comunicativa, contraposta à estratégia. Habermas (1987) defende a ideia de que a teoria da Ação Comunicativa demanda uma teoria da sociedade em que o sistema coloniza o mundo da vida. Habermas defende a ideia de que razão comunicativa opera na história como força redentora.

Uma situação de discurso ideal, precisamente porque confronta uma realidade contra factual, fundamenta a reflexividade na linguagem. O problema com o argumento não é sua relevância para a linguística, mas a sensatez de seus pressupostos teóricos e a possibilidade de sua tradução para categorias que esclareçam as maneiras historicamente determinadas pelas quais a realidade é constituída. Habermas está ciente da questão antropológica em jogo, de que a linguagem é intrinsecamente racional. Além disso, faz sentido ele ter iniciado Teoria da razão comunicativa com crítica de Max Weber, assumindo a divisão epistemológica entre sujeito e objeto em suas opiniões sobre a racionalização e gaiola de ferro (ROUANET, 1997, p.355). 
Para Habermas (1990) o agir comunicativo ou estratégico são necessários quando um ator só pode realizar seus planos de ação de modo interativo, isto é, com o auxílio da ação (ou da omissão) de outro ator. O agir comunicativo tem de satisfazer a condições de entendimento e de cooperação:

a) os atores participantes comportam-se cooperativamente e tentam colocar seus planos (no horizonte de um mundo da vida compartilhado) em sintonia uns com os outros na base de interpretações comuns da situação;

b) os atores envolvidos estão dispostos a atingir os objetivos mediatos da definição comum da situação e da coordenação da ação assumindo os papéis de falantes e ouvintes em processos de entendimento, portanto, pelo caminho da busca sincera ou sem reservas de fins ilocucionários (HABERMAS, 1990, p. 129).

Habermas (1990, p. 129) afirma que os atores:

perseguem seus fins ilocucionários com o auxílio de ações de fala num enfoque performativo, que exige que os atores se orientem por pretensões de validez, que são levantada alternadamente; ao fazer isso eles aproveitam os efeitos de ligação das ofertas contidas em atos de fala que surgem pelo fato de o falante assumir, junto com sua pretensão de validez, uma garantia fidedigna para a validade do que é dito; o efeito de compromisso inerente a uma ação de fala compreensível e aceita se transmite as obrigatoriedades resultantes do conteúdo semântico da ação de fala - seja assimetricamente para o ouvinte ou o falante, seja simetricamente para ambas partes.

Habermas (1990) faz uma distinção entre agir comunicativo e agir estratégico. O autor justifica que uma coordenação bem-sucedida da ação não depende da racionalidade teleológica das orientações da ação, mas da força racionalmente motivadora de realizações de entendimento, isto é, de uma racionalidade que se manifesta nas condições para um consenso obtido comunicativamente.

O entendimento linguístico funciona como mecanismo coordenador da ação, da seguinte maneira: os participantes da interação unem-se em torno da pretendida validade de suas ações de fala, ou seja, eles reconhecem intersubjetivamente pretensões de validez criticáveis. Uma vez mais, o que empresta às ofertas contidas nos atos de fala uma força racionalmente motivadora é o nexo estrutural que existe entre o significado de um proferimento, suas condições de validade, a pretensão de validez levantada em relação ao que é dito e as razões mobilizadas para o resgate discursivo dessa pretensão (HABERMAS, 1990, p. 130).

$\mathrm{Na}$ teoria consensual, a argumentação tem peso decisivo. A autoridade dos interlocutores não é tomada em consideração. A autoridade do interlocutor depende da competência de sua argumentação. A ética do consenso argumentativo é qualitativa e nunca quantitativa (estatística) ou autoritária. O consenso é válido para um determinado problema abordado em suas circunstâncias; é sempre provisório, no sentido que deve ser sempre retomado à luz de novas situações e circunstâncias.

A ética argumentativa nunca sacrifica a referência à pessoa, como lugar incondicional da ética. A ética argumentativa supõe que cada participante do diálogo venha com sua cultura, suas convicções e tradições com base nas quais formula sua argumentação ética. Portanto, quanto maior o lastro cultural dos participantes tanto mais valiosa será a solução de um problema. 
Há a ampliação e o enriquecimento da visão dos participantes, que podem romper com um passado estreito e individualista, abrir-se aos problemas gerais da humanidade e descobrir um sentido global na vida sociopolítica ; as pessoas podem concluir que nenhum problema ético tem solução pontual, mas que depende de um contexto amplo que exige princípios gerais estabelecidos pelo consenso de todos os interessados. Então, pelo diálogo argumentativo sobre problemas concretos, os interlocutores se elevam à universalidade dos princípios éticos dos quais partiam os clássicos.

A partir dos atos da fala, Habermas (1996) criou a teoria da ação, que pode ser utilizada (e instrumentalizada) basicamente como uma concepção convincente da racionalidade em relação ao discurso cotidiano que permite que se refute toda forma de relativismo como algo incoerente; no sentido de que a concepção da racionalidade comunicativa implica consequências políticas, isto porque sua perspectiva utópica de racionalização e liberdade está baseada nas condições de socialização dos indivíduos e inserta nos mecanismos linguísticos de reprodução da espécie humana e no sentido de quando a racionalidade é vista como razão instrumental, o potencial da razão comunicativa fica deslocado e distorcido no curso do desenvolvimento capitalista (da modernização capitalista), isto porque o desenvolvimento capitalista está associado a um "padrão seletivo de racionalização".

Desse modo, a Teoria da Ação (Comunicativa) de Habermas se propõe entender a modernidade ocidental sob a perspectiva da racionalidade cultural e societária e os efeitos do processo de racionalização sobre os atores sociais. A partir da compreensão da lógica estratégica; do sistema que organiza o mercado e o Estado; da lógica da racionalidade comunicativa que permite a organização da solidariedade e da identidade no interior do mundo da vida.

A partir dessa ideia Habermas traça um diagnóstico dos problemas contemporâneos das sociedades ocidentais através da utilização de um instrumental sociológico, que permite analisar a racionalização enquanto processo de diferenciação interna dos subsistemas da ação estratégica. E, ao mesmo tempo, privilegia a perspectiva dos atores na compreensão dos processos culturais, sociais e políticos. A análise de Habermas sobre a sociedade tem como objetivo de determiná-la enquanto esfera simultaneamente pública e política, cuja explicação da ação social se articularia com o movimento político de defesa da sociedade contra a penetração dos subsistemas em áreas organizadas em torno da reprodução de formas comunicativas de Ação.

Habermas parte do pressuposto de que o processo de desenvolvimento Capitalista Ocidental permitiu a ocorrência de um mecanismo de diferenciação das estruturas da racionalidade que contribuiu para que as estruturas sistêmicas se tornassem, cada vez, mais complexas em relação ao processo de racionalização comunicativa do mundo da vida.

A teoria da Ação de Habermas parte do suposto de que os homens agem como sujeitos dotados de capacidade de ação e que a concretizam, em conjunto, de acordo com a sua racionalidade (agem em função de uma razão, de interesses, no sentido Weberiano).

A concepção teórica de Habermas está voltada principalmente para a reconstrução das condições existentes (no sentido da totalidade Durkheiniana), pois os indivíduos, quando socializados, comunicam-se por meio da linguagem e não se tem como evitar o emprego dessa linguagem que está voltada para o entendimento; daí, a razão comunicativa, (HABERMAS, 1993, p.95-112). Portanto, a ação para Habermas expressa a intenção do agente em relação à realidade e, quando se afasta de uma relação intencional com a realidade (objetiva, social e subjetiva), perde qualquer conteúdo cognitivo, normativo e expressivo. Nesse sentido, destacam-se quatro tipos básicos de ações: a ação estratégica/teleológica; a ação normativa; a ação dramática e a ação comunicativa. A ação comunicativa se dá quando duas ou mais pessoas procuram expressamente chegar a um acordo voluntário de modo a poder cooperar. A ação comunicativa é constituída de sentidos compartilhados e envolve um esforço explícito e concentrado para alcançar um acordo sobre o espectro das reivindicações de validade. 
Ao se agir estrategicamente, podem-se forçar os outros a contribuírem para determinada meta, no sentido de emitir ordens, ameaças, mentiras e outras proposições manipuladoras.

Para Habermas, a prática cotidiana orientada para o entendimento está permeada de idealizações inevitáveis que permitem ao médium da linguagem coloquial a reprodução de nossa vida. Essas idealizações estão associadas aos conteúdos normativos encontráveis em nossas práticas das quais não podemos prescindir, porque a linguagem (associada à "visão do mudo") é constitutiva para as formas de vida socioculturais. HABERMAS, 1993).

No mundo da vida, compartilhamos intersubjetivamente um amplo consenso sem o qual a prática cotidiana não poderia funcionar. Portanto, sem esse consenso as pessoas não poderiam agir comunicativamente. $\mathrm{O}$ agir comunicativamente realiza-se através da linguagem comum, em um mundo explorado pela própria linguagem, pré-interpretado, em formas de vida compartilhada culturalmente, em contextos normativos, em tradições e rotinas. Entretanto, o agir comunicativo não significa a mesma coisa que argumentação, pois, a argumentação se expressa como formas de comunicação inverossímeis, ou seja, são formas de comunicação repletas de pressupostos que sustentam o agir estratégico.

O processo de racionalização do mundo faz com que Habermas faça a distinção entre sistema e mundo da vida. A diferença entre o mundo da vida e sistema refere-se não à distinção lógica entre funções integradas existentes em todas as sociedades como também pelo próprio processo evolucionário estabelecido pela racionalização do mundo da vida (pela lógica prática dos indivíduos). Essa distinção entre sistema e mundo da vida é importante para especificar as esferas da reprodução social (material e simbólica) que designam as funções integradas da sociedade (do sistema e do social) nos diferentes contextos da ação (estratégica e comunicativa). Essa diferenciação (entre mundo da vida e sistema) foi a que estabeleceu as diferenças entre o público e o privado.

Para compreender as diferenças entre o público e privado a partir do pensamento de Habermas, faz-se necessário entender que o autor procura mostrar que o conceito de racionalidade comunicativa difere da racionalidade instrumental e cognitiva e sustenta um conceito de sociedade que engloba o mundo da vida e o de sistema. Delineia uma teoria da modernidade que dê conta das novas patologias sociais como decorrência da submissão da ação comunicativa aos imperativos do sistema. Dar conta dos paradoxos da modernidade é um grande desafio que o autor enfrenta. Habermas mostra que as filosofias do sujeito se esgotaram. Somente a intersubjetividade fornece uma noção de estrutura racional imanente à ação comunicativa, fruto de uma razão encarnada simbolicamente e situada historicamente (Habermas, 1987, vol. I, p.11). Para Habermas, o predomínio do mercado, seu avanço para o Estado, o processo que ele chama de colonização do mundo da vida, não deve levar às atitudes conformistas dos neoconservadores, e nem à radicalização que produz a "desdiferenciação" entre mundo da vida e sistema. A modernidade criou condições para manter a vida social diferenciada do sistema. No pensamento habermasiano, o Sistema e Mundo da Vida são estruturalmente diferentes.

Quando se afirma a distinção entre o público e privado, percebe-se que a racionalidade não se limita à estrutura proposicional das afirmações acerca de fatos da realidade empírica. Para Habermas (1987), nas expressões linguísticas há um saber e nas ações dirigidas por um fim há um saber implícito. Uma afirmação comunica algo e uma ação visa a um fim, isto é, há um saber confiável, vinculado a uma racionalidade. Enquanto a racionalidade cognitivo-instrumental demanda êxito em intervir no mundo e capacidade de lidar com informações, o uso comunicativo decorre de um saber proposicional concretizado por atos de fala.

Essa razão comunicativa permite o consenso. A racionalidade comunicativa problematiza o mundo em função da necessidade de reconhecer as situações em sua objetividade, tendo em vista o entendimento entre sujeitos capazes de linguagem e de ação. $O$ entendimento depende dessa objetivação. A prática comunicativa cotidiana se dá no contexto do mundo da vida que (os falantes) compartilham intersubjetivamente (1987, vol. I, p. 31-31). 
Optar pelo modelo das manifestações simbólicas dos homens que encarnam saberes (convicções) intersubjetivamente partilhados, na teoria das organizações, opta-se por um conceito de racionalidade comunicativa. Esse conceito aponta para a capacidade de agir sem coações e de produzir consensos mediante a fala argumentativa, com o que os sujeitos da comunicação asseguram a unidade do mundo objetivo, a intersubjetividade do contexto em que desenvolvem suas vidas.

O Sistema integra as diversas atividades (da sociedade) no sentido de regular as consequências não pretendidas da ação estratégica por mecanismos de mercado ou burocráticos que limitam o escopo das decisões voluntárias. Em síntese, o conceito de sistema refere-se às implicações funcionais das ações para a reprodução de uma sociedade determinada.

O mundo da vida contribui para manter a identidade social e individual ao organizar a ação em torno de valores compartilhados, de modo a alcançar um acordo sobre aspectos de validade que são passíveis de crítica. Em síntese, o mundo da vida se traduz através de mecanismos pelos quais os agentes sociais chegam a uma compreensão compartilhada do mundo ("Visão de mundo").

A separação entre mundo da vida e sistema ocorre em sociedades estratificadas em classes e organizadas pelo Estado, onde a integração do sistema ao mundo da vida está condicionada à sua própria racionalização. Desse modo, reduz-se, gradativamente, o mundo da vida a um apêndice do sistema (através da racionalidade instrumentalizada). Este mecanismo de redução permite que áreas inteiras (da produção e da reprodução) sejam transferidas para o sistema (o que Habermas chama de geração de valor).

Entretanto, Habermas observa duas tendências contrárias que surgem a partir da generalização do valor: de um lado, a comunicação orientada para o consenso torna-se tão geral na sua aplicação, que toda interação exige, cada vez mais, uma justificação imediata e uma longa negociação. De outro lado, a comunicação pode ser generalizada mediante os meios de comunicação de massa de forma que servem para construir tal tendência.

Desse modo, a comunicação é liberada de perigo constante da disseminação por dois mecanismos: o de condensar a comunicação; e o de substituí-la pela ação orientada para o êxodo. Estes mecanismos, por sua vez, possibilitam a aplicação de dois métodos para induzir a aceitação: o da autoridade e o do prestígio. Ambos podem ser empregados para motivar a ação estrategicamente (no sentido empírico) ou consensualmente (no sentido racional). Para Habermas, a condensação da ação comunicativa tem vantagens e desvantagens, embora seja indispensável para gerar consenso; ela possui um potencial de abuso manipulativo nas sociedades contemporâneas.

Para ele os problemas do Sistema não são sempre econômicos, mas derivados, geralmente, da base social. Entretanto, só a sociedade capitalista, como consequência da institucionalização formal, permite um mecanismo baseado exclusivamente no mercado para regular o acesso à propriedade e à distribuição de riqueza. A distribuição desigual da riqueza, nas sociedades capitalistas, gera novos problemas de conflito de classe. Esses conflitos são contidos por mecanismos de despolitização das relações de classe, onde o Estado garante as condições gerais de produção e de reprodução, através da lei e da ordem que propiciam, de modo sistemático, a educação, transporte e comunicação, mas deixam o mercado inviolável. Existem muitos mecanismos de controle, o problema é que esses mecanismos são corrompidos pela força política e pelo fascínio exercido pela possibilidade de poder e de aquisição de bens advindos do poder econômico.

A função do mercado é liberar a ordem política das pressões em favor da legitimação (no sentido da lei). Assim, a ideologia burguesa oculta a exploração do trabalho através da fachada impessoal dos contratos de trabalho involuntários (no sentido das condições de liberdade universal na troca de equivalentes no mercado). Desse modo, o conflito de classes se desloca da arena politizada da interação social para o domínio não normativo e impessoal das transações do mercado. Descolando-se, assim, o eixo das relações de produção e de acumulação de capital para a demanda de consumidores (transmutam-se produtores e vendedores de força de trabalho em consumidores de bens e serviços). 
Na construção teórica sobre o mundo da vida, Habermas fundamenta-se em Weber em dois aspectos: 1) Em relação à questão da diferenciação entre "âmbitos culturais independentes", onde a ciência, o direito, a moralidade e a arte constituem práticas culturais independentes, cada uma é regulada por seus princípios próprios e específicos. Este processo de autonomização envolve, segundo Habermas, a "racionalização das imagens do mundo". Há uma desfetichização do mundo na medida em que se separa natureza da cultura e se traça uma distinção entre mundo físico, governado por leis causais, e o mundo humano, permeado de significados e propósitos. Nesta distinção, a natureza deixa de ser uma projeção das preocupações humanas. Este processo de racionalização implica a formalização da mesma razão. Segundo Habermas, a racionalidade já não consiste em certas ideias substantivas, senão nos procedimentos que sustentam as ideias e estão implícitos em todo ato de fala. 2) A modernização implica uma segunda forma de diferenciação que se estabelece entre sistema e mundo da vida. É condição necessária para o desenvolvimento do capitalismo que a integração sistêmica se desprenda da integração social, como vimos. A reprodução da sociedade depende, cada vez mais, do surgimento de mecanismos sistêmicos que estabilizam nexos de ação não-pretendidos, mediante um entrelaçamento funcional das consequências da ação.

Em relação ao mundo da vida, há níveis de comunicação: a interação mediada por símbolos entre falante $(\mathrm{F})$ e ouvinte $(\mathrm{O})$; o conteúdo proposicional do discurso difere conforme se trata de uma ação ou de uma fala; no discurso argumentativo, F e O expõem pretensões de validez justificáveis. É oportuno destacar que cada forma de integração social requer um novo processo evolutivo de aprendizagem. Para Habermas, na modernidade a ação moral é pós-convencional, o agir estratégico organiza-se de forma universal no capitalismo. Percebe-se que, nos quadros institucionais de democracias formais, o direito burguês afirma-se independentemente do poder político. Legalidade e moralidade se separam, a moral provada guia-se por princípios do direito formal, geral e racionalizado.

Os modelos de racionalidade remontam às duas relações fundamentais em que o homem se envolve ao realizar suas ações: as relações com a natureza e as relações com os outros homens. Com a natureza a relação é de conhecimento e de domínio; com os outros homens a relação tem a característica básica de uma interação simbolicamente mediada. (OLIVEIRA, 1989a, p.15-16).

A noção de "racionalidade" emerge exatamente dessa capacidade de os homens agirem sobre a natureza e de interagir com os outros homens. Na realidade somente às pessoas atribuímos o predicado de racionais ou de irracionais, e isso tão somente sob o ponto de vista do que falam, ou do que fazem. Interagindo pela fala ou agindo pela intervenção na natureza, as pessoas podem comportar-se de forma mais ou menos racional.

O que determina a racionalidade de uma fala ou de uma ação? Percebe-se em primeiro lugar que há uma estreita relação entre racionalidade e saber, mas Habermas argumenta que a racionalidade diz respeito nem tanto ao saber em si ou à sua aquisição, e sim à forma como os sujeitos capazes de linguagem e de ação fazem uso desse saber (HABERMAS, 1992i, p.24).

Sendo que o critério de racionalidade está na forma como os sujeitos fazem uso do saber encarnado em suas ações e manifestações simbólicas, podemos chamar de racional o sujeito que é capaz de fundamentar a convicção que motiva sua ação ou sua fala e que, em princípio, sempre é susceptível de crítica. Assim, tanto nas suas ações sobre a natureza como nas suas manifestações simbólicas, um sujeito pode ser considerado racional, à medida que age de modo intencional, isto é, persegue um sentido motivado e fundamentado.

No caso de uma ação sobre a natureza, a racionalidade reside na capacidade de o agente dar garantias, a um possível observador crítico, de que sua intervenção alcançará o êxito esperado, isto é, que será eficaz. Já no caso de uma manifestação simbólica, a racionalidade reside na capacidade de o falante justificar, caso seja questionado por algum interlocutor, que sua opinião é verdadeira, justa ou sincera, ou seja, que ela é válida (HABERMAS, 1992, p.28).

A análise das ações do homem sobre a natureza explicita um conjunto de regras técnicas fundamentais num saber empírico que aponta para as condições necessárias a uma 
intervenção, eficiente do ponto de vista causal, no mundo dos estados de coisas existentes. (HABERMAS, 1990a, p.70).

Como essas regras técnicas enfatizam a busca dos fins previamente definidos, sob determinadas condições, temos aí o modelo de uma racionalidade cognitivo-instrumental.

A análise das manifestações simbólicas por sua vez revela a operacionalidade de um conjunto de normas que aponta para as "condições de validade exigidas para atos de fala, por pretensões de validez, que se manifestam através de atos de fala, e por razões para o resgate discursivo dessas pretensões". (HABERMAS, 1990a, p.70).

Nas manifestações simbólicas os sujeitos estabelecem expectativas recíprocas de comportamento visando à compreensão e ao reconhecimento de convicções. As normas se orientam para a construção da vida intersubjetiva, configurando o modelo de uma racionalidade comunicativa.

Segundo Habermas (1992, p.27), se for tomada como modelo as ações do homem sobre a natureza, em que há a utilização de um saber (conviçção) não comunicativo, estar-se-á optando por um conceito de racionalidade cognitivo-instrumental que tem a conotação de uma autoafirmação em êxito no mundo objetivo possibilitada pela capacidade de manipular informadamente e de adaptar-se inteligentemente às condições de um entorno contingente.

Mas, se a opção for tomar como modelo as manifestações simbólicas dos homens que encarnam saberes, convicções, intersubjetivamente partilhados, vai se estar optando por um conceito de racionalidade comunicativa. Esse conceito aponta para a capacidade de agir sem coações e de produzir consensos mediante a fala argumentativa. Tanto as ações de caráter cognitivo-instrumental como as ações orientadas ao entendimento são comuns e indispensáveis no planejamento estratégico de uma organização. O agir estratégico não pode ser concebido simplesmente como uma manipulação instrumental.

O agir comunicativo resulta da aplicação, em contextos de ação social, do modelo de racionalidade que emana dos processos de entendimento de validez criticáveis. A linguagem aparece com todo o seu potencial de motivar a convicção e de gerar consenso.

Só o conceito de agir comunicativo pressupõe a linguagem como um meio de entendimento em que falantes e ouvintes se referem, a partir do horizonte pré-interpretado representado pelo mundo da vida, simultaneamente a algo no mundo objetivo, social e subjetivo, a fim de negociar definições da situação que possam ser compartilhados por todos (HABERMAS, 1987, vol. I, p. 138).

O Agir estratégico que resulta somente do modelo da racionalidade que emana dos processos de intervenção na natureza com o fim de uma manipulação com êxito não passa de um meio de transmissão de informações e de influência de uns sobre os outros e sobre a situação da ação, induzindo o comportamento.

É importante notar que o aspecto cognitivo-instrumental não fica excluído da reflexão habermasiana, mas é integrado como momento particular de uma ideia de racionalidade mais ampla. A racionalidade comunicativa tem essa maior amplitude e, é um conceito mais rico, porque a linguagem permite que se estabeleça um entendimento não só acerca de objetos dos quais se possa predicar a verdade, mas também sobre normas e vivências que podem ser justas ou sinceras. Com isso, além do elemento cognitivoinstrumental, a racionalidade comunicativa permite integrar também os elementos prático-moral e estéticoexpressivo (HABERMAS, 1990b, p.291). 


\section{Razão Substantiva - Guerreiro Ramos}

Antes de discutir uma das teses fundamentais do pensamento de Guerreiro Ramos, a Teoria Substantiva da vida Humana associada, cabe destacar que Ramos (1989) reconhece que a noção de racionalidade é soberana em Habermas. Para Ramos (1989, p. 10), "ao contrário de Weber, Habermas nãos suspende os padrões éticos quando se volta para o tema da racionalidade nas sociedades modernas".

Ramos destaca nas suas reflexões que no pensamento de Habermas há um sobretom sociomórfico de uma teoria destinada ao esclarecimento que promete o esclarecimento existencial como uma qualidade coletiva do comportamento da massa, quando o esclarecimento tem sido sempre possível apenas ao nível da psique individual (RAMOS, 1989, p.20).

De acordo com Ramos (1989), Weber, ao distinguir a racionalidade instrumental (funcional) e a racionalidade de valor, sugere que tanto uma como outra poderiam servir de referência teórica, embora em a "Ética Protestante e o Espírito do Capitalismo" ele tenha feito, sobretudo, uma análise a partir da racionalidade instrumental (funcional). A racionalidade de valor, definida por Weber (1999) como aquela cujas ações se dão independentemente dos resultados esperados, porque são baseadas em valores absolutos tais como a ética, a estética e a moral, é denominada por Mannheim (1962) como racionalidade substancial.

Para Mannheim, a racionalidade substancial são os atos de pensamento que revelam percepções inteligentes das inter-relações dos acontecimentos e de determinadas situações, enquanto a racionalidade instrumental (funcional) é concebida como uma série de medidas organizadas de forma a levar a um objetivo previamente definido. Entretanto, Mannheim, a exemplo de Weber, não aprofunda a análise da racionalidade substancial tal como o faz em relação à racionalidade instrumental (funcional) (talvez porque ambos não encontrem lastro na realidade empírica, na qual predomina a racionalidade instrumental), preferindo basear-se, sobretudo, na racionalidade instrumental (funcional) para suas análises.

O mesmo ocorre com a teoria crítica da Escola de Frankfurt que, com exceção dos trabalhos de Habermas, supra discutidos, fundamenta-se prioritariamente na noção de racionalidade instrumental (formal-funcionalsubjetiva). Entretanto, Weber, Mannheim, Horkheimer e Adorno, ao desenvolverem a noção da racionalidade instrumental, como descritivas da racionalidade predominante na sociedade, não negligenciam a racionalidade substantiva, mas justamente a têm como ponto de referência para a crítica que fazem à sobreposição da racionalização instrumental em relação a outras racionalidades presentes na sociedade.

Ramos, contudo, baseando-se em Weber, tenta resgatar a noção de racionalidade substantiva, não só como categoria de análise ou como contraponto para a crítica da racionalidade instrumental, mas como critério de transformação social. Para ele, tanto a racionalidade instrumental (funcional) como a racionalidade substantiva são categorias fundamentais de duas concepções distintas da vida humana. Esta última, ele alude, a título de especulação, "poderia ser formulada com base naquilo que Weber não disse, mas que provavelmente diria se tivesse vivido nas presentes circunstâncias históricas". Segundo Ramos, do ponto de vista de Weber, "os valores adotados por uma sociedade são, eles próprios, critérios indicadores daqueles pontos que são importantes para aquela forma particular de vida humana associada, durante certo período histórico" (RAMOS, 1989, p. 25). Focalizar esses valores, portanto, não tira absolutamente o caráter de neutralidade da ciência, senão apenas quando esta emitir algum julgamento de valor.

Essa posição de Weber, segundo Ramos, mereceu críticas de autores como Voegelin (1952) e Strauss (1953), para os quais é impossível fazer uma análise objetiva de valores (RAMOS, 1989, p. 26). Entretanto, continua Ramos, "Weber viveu num contexto histórico em que a racionalidade formal ou funcional substituía amplamente a racionalidade substantiva como o principal critério de ordenação dos negócios políticos e sociais" (RAMOS, 1989, p. 26), motivo pelo qual não se construiu uma ciência social com base na noção de racionalidade substantiva. O que denota, com efeito, absoluta coerência, já que em Weber, o conceito de racionalidade é um conceito analítico. Isto é, meio para abstrair da ação e da relação social os seus significados explícitos e subjacentes, como as motivações que culminam nas ações e as próprias relações 
sociais. Portanto, não se trata de um conceito sem lastro na realidade, mas justamente o contrário, ele é desenvolvido a partir de fenômenos sociais vislumbrados no mundo-da-vida.

A questão que preocupa Ramos, porém, é se no seu contexto histórico (segunda metade do século XX) a razão substantiva poderia ser uma categoria essencial para pensar as problemáticas sociais e políticas. Ele tenta, a exemplo de alguns autores da Escola de Frankfurt, restabelecer a razão como uma categoria ética. Para tanto, parte da concepção aristotélica de razão ${ }^{3}$, segundo a qual a razão é uma característica sui generis do homem, que é, por conseguinte, um "animal político" dotado de percepção das suas atividades racionais e de sua psique. Resulta também do contexto histórico-cultural que, no seu entendimento, constitui o elemento distinto de uma teoria substantiva da vida humana associada, pelo fato de que essa faculdade racional, por um lado é configurada por uma época e por uma cultura e, por outro lado, deve transcender a configuração e a determinação social imposta particularmente, deixando prevalecer a determinação do ser racional enquanto ser político no sentido aristotélico.

Nesse sentido, Ramos afirma:

Pelo exercício da razão, e vivendo de acordo com os imperativos éticos dessa razão, o homem transcende a condição de um ser puramente natural e socialmente determinado, e se transforma num ator político. A definição que Aristóteles deu do homem como um 'animal político' (zoon politikon) só é compreensível à luz desse entendimento. (...). No domínio político, o homem é destinado a agir por si mesmo, como um portador da razão no sentido substantivo (RAMOS, 1989, p. 28-30).

Esta concepção de homem político, cuja consciência crítica é altamente desenvolvida sobre as premissas de valores substantivos presentes em seu dia-a-dia, Ramos (2001) denomina de "homem parentético". Conforme o autor, o conceito deriva da noção de Husserl de "suspensão", de estar "entre parênteses", e segundo a qual, "a atitude 'crítica' suspende ou põe 'entre parênteses' a crença no mundo comum, permitindo ao indivíduo atingir um nível de reflexão conceitual e, portanto, de liberdade" (RAMOS, 2001, p. 06). Este entendimento de Ramos é congruente ao de Habermas e é fundamental, pois elimina a confusão, muitas vezes frequente na literatura, entre racionalidade de valor e racionalidade substantiva. Como já ressalvado no início deste ensaio, a racionalidade substantiva não é uma racionalidade de valor, mas uma racionalidade política libertária, de emancipação do individuo (FERNANDES, 2008).

Aristóteles, segundo Ramos, tinha a percepção de que na medida em que os "interesses práticos constituem o único critério para as ações humanas, não existe nenhuma vida política". É o que Ramos denomina transavaliação social, que ocorre a partir da transavaliação da razão. A transavaliação da razão consiste na transformação dos "meios" em "fins" e na incapacidade de julgá-los com base nos critérios da racionalidade substantiva, senão apenas pela sua instrumentalidade e funcionalidade. A transavaliação social é a separação da atividade social da atividade política e a perda dos seus valores intrínsecos e criticidade, privilegiando apenas seus aspectos instrumentais e transformando a ação social em apolítica resignada a processos autômatos. Na medida em que os padrões e critérios socialmente estabelecidos regem a existência humana em seu conjunto, a sociedade moldada pelos anseios capitalistas torna-se o único mentor do ser humano, que, por sua vez, é reduzido a uma criatura capaz de cálculo e, consequentemente, incapaz de distinguir entre o vício e a virtude (RAMOS, 1989). Sob os critérios da razão instrumental (formal-funcional) o domínio de anseios socialmente construídos prevalece sobre o homem, tornando-o exclusivamente um ser social, sob a

\footnotetext{
${ }^{3}$ Aristóteles primeiro define o homem como um animal, situando-o numa grande classe genérica (a classe dos animais), e em seguida Ihe dá uma característica própria e exclusiva que o distingue de todos os demais animais, que é a razão (DURANT, 2000). A razão no sentido aristotélico, portanto, pode ser definida como a característica atribuída ao homem, como o que o difere dos demais animais, a sua característica exclusiva (ARISTÓTELES, 2000; LOCKE, 2000; LEIBNIZ, 2000, KANT 2000). Esses pensadores, segundo Ramos estavam preocupados com a característica sui generis do homem. "Essa característica é a percepção que o homem tem da atividade da razão em sua psique" (RAMOS, 1989, p. 28).
} 
forma de um agente econômico, produtor e consumidor, produto da racionalização, em detrimento do ser político. O indivíduo dominado socialmente (pelo simbólico dominante no capitalismo - produção e consumo como sinônimo de poder e status - tornou-se incapaz de raciocinar porque é esmagado pela vida racionalizada e pelo conhecimento abrangente, que está além da sua capacidade (SIMON, 1973, segundo RAMOS, 1989).

A razão substantiva é a razão do homem como ser político "que delibera sobre coisas porque está consciente de suas finalidades intrínsecas" (RAMOS, 1989, p. 51) e suas ações constituem uma forma ética de conduta. A concepção de uma racionalidade substantiva é o reconhecimento de que os elementos éticos, morais e estéticos - entre outros valores - são critérios ponderáveis e vão influenciar, dando sentido, qualificando, tipificando, peculiarizando ou alegoricamente configurando a ação social, transformando-a em ação sociopolítica consciente. A racionalidade substantiva, assim, como a capacidade de ponderação de critérios não necessariamente instrumentais, valorativos, simbólicos e subjetivos, e não como racionalização funcional, porque sob os critérios da racionalidade substantiva, "os seres humanos são levados a agir, a tomar decisões e a fazer escolhas, porque causas finais - e não apenas causas eficientes influem no mundo em geral". Portanto, a razão substantiva é aquela que capacita os seres humanos a compreenderem a história e a própria condição humana (RAMOS, 1989, p. 51).

Por esse motivo, de acordo com Ramos (1989), a reversão da transavaliação da razão e consequentemente da transavaliação social, implica, ainda, uma reversão epistemológica, na medida em que a análise da sociedade moderna seja feita a partir do conceito de racionalidade substantiva e de seus critérios, ao invés de ser feita a partir do conceito de racionalidade instrumental e dos critérios de eficácia, rendimento e desempenho, como se tornou comum. O conceito de economia certamente seria outro, assim como a própria noção de progresso e desenvolvimento, desfazendo a inversão denunciada pela Escola de Frankfurt e por outros autores como Gorz, Ilich e Morin, provocando também a reversão da transavaliação social.

Guerreiro Ramos, embora se baseie muito em Weber, constrói um conceito de racionalidade substantiva que vai além da proposição weberiana. Weber propõe o conceito de racionalidade como uma categoria de análise, ou seja, como uma espécie de lente que permite enxergar determinada realidade e suas peculiaridades, o que retrata a ação social. É assim que o pensador alemão caracteriza a ação social e econômica dos puritanos: como uma ação social que tem um fim claro, em função da qual eles passam a viver. Já em Ramos, essa categoria analítica transforma-se em um instrumento de ação e planejamento social. O objetivo principal de Guerreiro Ramos é justamente o de propor um "conceito de racionalidade mais sadio". Ramos está em busca não apenas de categorias de análise, mas de critérios de intervenção no mundo. A sua preocupação é construir critérios mais saudáveis para o planejamento de sistemas sociais, nos quais o termo saudável quer dizer incluir as múltiplas dimensões do humano. Guerreiro Ramos acreditava que uma teoria substantiva das organizações poderia influir nos sistemas sociais, possibilitando uma vida mais sadia para o ser humano, via intervenção política, antecipando inclusive o debate ambientalista nesse sentido. Ele denuncia que os sistemas sociais estavam sendo planejados apenas com base nos critérios da racionalidade instrumental, trazendo sérios problemas para a vida humana em sociedade, tais como problemas psicológicos e sociais (individualismo, alienação, desintegração, eliminação da cooperação e da solidariedade) e degradação socioambiental (desigualdade social, degradação ambiental).

A importância da formulação de Guerreiro Ramos está justamente no fato de o autor resgatar e tentar estabelecer critérios para a ação humana a partir da formulação de um conceito de racionalidade substantiva. Entretanto, esse conceito só faz sentido se tiver lastro no mundo-da-vida, conforme a análise de Habermas. Da mesma forma que não se pode afirmar que o fato dos sistemas sociais serem planejados e desenvolvidos com base em critérios predominantemente instrumentais se deve à existência de um conceito de racionalidade instrumental, também não é possível afirmar que a falta de critérios mais substantivos nos sistemas sociais se deva a não existência de um conceito construído com base em critérios mais substantivos. O critério instrumental, com bem demonstrou Weber, e como pode ser observado mais ainda atualmente, sempre foi predominante no sistema capitalista. Entretanto, isso não quer dizer que não existam outros critérios mais substantivos ou axiológicos de racionalidade na sociedade. Existem muitos trabalhos que 
demonstram, a partir de experiências sociais diversas, que esses critérios, embora não sendo predominantes, fazem-se presentes na ação social. Essas experiências, contudo, não se devem à existência de conceitos que as caracterize e as retrate. Por outro lado - e não é possível precisar em que medida - a expansão dessas experiências depende em parte de conceitos precisos que as definam, como tem se tentado fazer com as experiências Economia Social e Solidária. Todavia, são conceitos com natureza epistemológica que uma vez definidos passam a servir tanto para os agentes da experiência - empresários e trabalhadores - como para os analisadores, como parâmetros e modelo, expandindo-se e se tornando uma espécie de "senso comum". E nisso reside a grande contribuição de Ramos, no sentido de construir uma teoria que contempla tanto a racionalidade instrumental como a racionalidade substantiva, cujo objetivo é expandi-la a ponto de se tornar base para o planejamento e desenvolvimento dos sistemas sociais, embora lhe faltasse o lastro empírico ${ }^{4}$.

A discussão epistemológica sobre o enquadramento do conceito de racionalidade como uma categoria que, além de instrumento analítico, constitua-se em proposta ideológica ou conjunto de postulados ou ainda propostas de sociedade (como é o caso das experiências acima mencionadas) é algo que se está por fazer na literatura e não responde aos objetivos deste ensaio. O conceito de racionalidade - instrumental ou substantiva - só pode ser extraído de uma realidade social, da ação social e de suas peculiaridades, como fez Weber. Ele serve de diagnóstico parcial dessa mesma realidade. Diz-se parcial, porque a sociedade é vista a partir de um olhar: o da racionalidade 5 .

\section{Racionalidade Ambiental - Enrique Leff}

Enrique Leff chama atenção ao fato de que o saber ambiental ficou excluído num processo de extermínio dos saberes não-científicos (saberes errantes, ciganos, nômades), [onde se incluem os saberes culturais populares] no campo de concentração das externalidades do sistema econômico, social e político, bem como o científico-tecnológico dominante (Leff, 2001, p. 30). Nesse sentido, baseando-se principalmente nas tipologias de racionalidade formal (instrumental) e de valor (substantiva) de Max Weber e numa perspectiva construtivista, Leff (2001) formula o ensaio denominado racionalidade ambiental. Segundo suas próprias palavras, "a construção desta racionalidade ambiental aparece como um processo de produção teórica, desenvolvimento tecnológico, mudanças institucionais e transformação social" (grifo original) (LEFF, 2001, p. 110). Além disso, de acordo com este autor, a construção da racionalidade ambiental é um processo que passa pela reforma do Estado, pela incorporação de normas ao comportamento econômico, e pela internalização das externalidades ambientais. Estas ações não devem ocorrer, porém, com base apenas nas regras do mercado, mas também com base nos critérios subjetivos e subjacentes do processo de desenvolvimento e das relações sociais e suas organizações, presentes nos processos políticos, na legislação, nos procedimentos de gestão e nos processos sociais e produtivos. Especificamente, no caso da racionalidade ambiental, na legislação, educação e processos de gestão e de controle da poluição.

A racionalidade ambiental, personificada pelo movimento ambientalista e pela própria problemática ambiental, segundo Leff, é um movimento contrário à razão baseada apenas no cálculo econômico como critério predominante da racionalidade social; ela expõe fundamentalmente as contradições entre a lógica da racionalidade econômica e do processo de desenvolvimento baseado no crescimento econômico e a sustentação desse desenvolvimento pela natureza. A racionalidade ambiental, a exemplo da formulação de uma racionalidade substantiva feita por Habermas (1981, 1990, 1991, 1992, 1993), e posteriormente por

4 Embora sem citar Ramos, Boaventura de Sousa Santos também propõe algo parecido, "da ciência moderna ao novo senso comum" (SANTOS, 2000).

${ }^{5}$ Essas reflexões são resultados das discussões com Maurício C. Serafim, pesquisador, conhecedor de Guerreiro Ramos. Embora discorde de Serafim em muitos pontos sobre a proposição de Ramos, principalmente sobre a natureza epistemológica do conceito de racionalidade substantiva, é justo registrar que muitas das ideias acima são dele ou resultado do diálogo com ele. 
Ramos (1989), "questiona as teorias sociais que legitimaram e instrumentalizaram a racionalidade social prevalecente e defende a necessidade de elaborar novos paradigmas de conhecimento para construir outra realidade social" (grifo original) (LEFF, 2001, p. 146). Ela surge tanto a partir do "paradigma ambiental" nas ciências de modo geral, comportando mudanças nas regras metodológicas e epistemológicas, como pela influência nas "formações ideológicas, sistemas de valores, crenças, conhecimentos e práticas produtivas, sobre os diferentes processos e elementos - naturais e sociais - que constituem o ambiente, suas relações e seus potenciais" (LEFF, 2001, p. 144).

A racionalidade ambiental, na concepção de Leff, "surge assim, como um conjunto de processos de racionalização com diferentes instâncias de racionalidades que conferem legitimidade à tomada de decisões com respeito à transformação da natureza e do uso dos recursos" (LEFF, 2001, p. 134). Leff distingue esses processos de racionalização em cinco tipologias constituintes e inerentes do processo de construção da racionalidade ambiental: a racionalidade substantiva; a racionalidade ambiental teórica; a racionalidade ambiental técnica ou instrumental; a racionalidade ambiental cultural e a racionalidade ambiental econômica.

A racionalidade ambiental cultural, na concepção de Leff (2001, p. 134), implica reconhecer a diversidade étnica e suas relações com o meio ambiente e "não é apenas um argumento a mais da racionalidade substantiva, e sim constitui também um princípio que normatiza toda a racionalidade instrumental". Essa afirmação de Leff é pertinente em termos de conteúdo cultural, na medida em que considera que cada cultura é constituída tanto por critérios de lógica instrumental como de lógica substantiva e que ambos podem ser aproveitados no processo de gestão ambiental. Entretanto, é bastante discutível no que se refere aos seus aspectos lógicos e metodológicos, pois transforma a cultura em aspecto da racionalidade e não o contrário. São as culturas que contêm as racionalidades e não as racionalidades que contêm as culturas, ao contrário do que acredita Leff. Portanto, seguindo o modelo weberiano, não é possível falar em uma racionalidade cultural, mas na presença ou preponderância de racionalidades (instrumental ou substantiva) na cultura.

A racionalidade ambiental econômica concerne aos processos de transformação da natureza, os usos dos seus recursos, bem como sua gestão. Portanto, uma racionalidade ambiental econômica responde pela concepção de novos processos produtivos, que não devem estar baseados apenas na racionalidade instrumental como se consagrou na racionalidade econômica capitalista. A racionalidade ambiental econômica deve aproveitar a racionalidade instrumental, incorporando no processo mercadológico, o chamado "potencial ambiental", que nada mais é que, além de produzir respeitando e conservando a natureza, desenvolver um mercado para produtos "ecologicamente corretos" que ganham notoriedade a partir do apelo ético e moral, apostando, portanto, também na existência de um "suporte" da racionalidade substantiva. Além disso, embora Leff não chegue a esta concepção, poder-se-ia acrescentar que uma racionalidade ambiental econômica, incorpora a orientação subjetiva da gestão econômica, tal como propõe Weber, cujo princípio é a provisão (no sentido de poupar, conservar a natureza e não a dilapidação imediata), baseando-se num pensamento de longo prazo e de caráter essencialmente administrativo fundado na noção de previdência intergeracional.

A racionalidade ambiental teórica, nas próprias palavras de Leff, "apresenta-se como uma produção conceitual orientada para a construção de uma racionalidade produtiva alternativa" (LEFF, 2001, p. 132). Nesse sentido, embora não esteja claro na proposição de Leff, podem ser destacados dois aspectos fundamentais: o surgimento da problemática ambiental, enquanto processo sociopolítico que dialoga com os processos econômicos, produtivos, de produção tecnológica e de conhecimento; e o surgimento da ideologia ambiental, presente no movimento ambientalista e na sociedade civil organizada de modo geral, incluindo setores da ciência. Esse dois aspectos dão legitimidade e suporte à construção de uma racionalidade produtiva alternativa que leve em conta a articulação entre a ecologia e a cultura, a partir das quais são desenvolvidas as tecnológicas e as práticas científicas e os próprios processos produtivos, conforme propõe o autor. A racionalidade ambiental teórica fornece, portanto, o aporte para um desenvolvimento alternativo, baseado numa racionalidade produtiva alternativa. Embora Leff não cite, uma racionalidade produtiva traz inerente ao seu desenvolvimento uma racionalidade de consumo que, na racionalidade capitalista tem efeitos 
tão perversos sobre a sociedade e sobre a natureza como o próprio processo produtivo, conforme afirmam autores como Mannheim, Horkeimer, Gorz e Illich.

A racionalidade técnica ou instrumental é aquela que, de acordo com Leff (2001, p. 133), "estabelece os meios que conferem sua eficácia à gestão ambiental, incluindo as tecnologias ambientais e ecotécnicas, as ordenações jurídicas, os instrumentos legais, e os arranjos institucionais das políticas ambientais...”. O autor apoia-se, em termos teóricos, no conceito de racionalidade instrumental e, em termos práticos, no aparato técnico, legal e institucional, desenvolvidos como meios regulatórios de proteção e reparação de danos ambientais e de prevenção e despoluição. A racionalidade instrumental contida em processos de gestão ambiental, segundo Leff, significa que a racionalidade social não é algo abstrato no tocante a essa questão, mas resulta de um conjunto de normas e ações sociais e governamentais, impedindo que a gestão ambiental fique à mercê apenas das leis de mercado.

A racionalidade substantiva é aquela a partir da qual emerge a consciência ambiental, assim como novos critérios, valores e princípios questionadores da racionalidade econômica. Segundo Leff:

Estes critérios, princípios e valores, devem ser sistematizados e operacionalizados por meio de conceitos, teorias e técnicas que os articulem com suas bases materiais (...), pela organização de políticas científicas, organização de movimentos sociais e estratégias políticas e a elaboração de instrumentos tecnológicos e normas jurídicas, que permitam sua tradução em processos produtivos alternativos para a gestão dos recursos ambientais das comunidades e um desenvolvimento sustentável em nível planetário (LEFF, 2001, p. 132).

Consequentemente é o espírito que deve reger as ações que visem construir um desenvolvimento equitativo e sustentável. Nesse sentido, a racionalidade ambiental, tal como propõe Leff (2001), comporta tanto aspectos instrumentais como aspectos substantivos e subjetivos. Trata-se de uma tentativa de conjugar os aspectos formais da sociedade (o aparato estatal e a economia) com os aspectos substantivos desenvolvidos pelo ambientalismo. Leff fundamenta-se no fato de que no decorrer destes anos de reconhecimento da crise ambiental, por um lado, elaborou-se de forma heurística um conjunto de princípios morais e conceituais de base holística, democrática, participativa, cooperativa e intergeracional, que sustentam uma teoria alternativa do desenvolvimento e o próprio movimento ambientalista. Por outro lado, foram construídos diversos mecanismos e instrumentos sociais, institucionais, tecnológicos e políticos, em parte fundamentados nesses princípios e em parte incorporados na estrutura social, econômica, institucional, política e estatal vigente. Esses mecanismos são legais, institucionais, de políticas públicas, tecnologias de gestão, de prevenção e de despoluição, entre outros. A construção e operacionalização destes mecanismos na prática é um movimento de inserção do critério ambiental na racionalidade social e produtiva.

O caráter instrumental desse movimento resulta da operacionalização em termos de transformação social, na medida em que os critérios ambientais e sociais tornam-se ações e normas que influem no processo de desenvolvimento, sendo que esses critérios, com o tempo, ganham funcionalidade e se transformam em fenômenos quotidianos e culturalmente intrínsecos. Nas próprias palavras de Leff, trata-se de:

Uma racionalidade ambiental não é expressão de uma lógica, mas o efeito de um conjunto de práticas sociais e culturais diversas e heterogêneas, que dão sentido e organizam os processos sociais por intermédio de certas regras, meios e fins socialmente construídos, que ultrapassam as leis derivadas da estrutura de um modo de produção (LEFF, 2001, p. 125).

Seu caráter substantivo resulta, por sua vez, do conjunto de normas e ações sociais que regulam e limitam as leis do mercado em relação ao uso da natureza, seja através do Estado e do seu aparato institucional, seja através da sociedade civil organizada e politizada. A racionalidade ambiental tem caráter substantivo, primeiro, quando é pensada enquanto processo político e de conscientização, submetendo o processo de desenvolvimento ao julgamento de valores absolutos (morais, éticos e estéticos); segundo, na medida em que 
a problemática ambiental é considerada em si uma problemática não só de ordem prática (exaustão de recursos naturais, extinção de espécies, saúde pública), mas também de ordem ética, moral e estética que envolve necessariamente processos sociais e políticos.

As formações teóricas e ideológicas, bem como as práticas do ambientalismo emergem [por um lado] com um sentido prospectivo, reorientando valores, [e por outro] instrumentalizando normas e estabelecendo políticas para construir uma nova racionalidade social (LEFF, 2001, p. 112, grifo original).

É substantiva, ainda, quando a racionalidade ambiental não é nem somente uma racionalidade ecológica, que copia a lógica da natureza, nem somente uma racionalidade social, que a ignora. É substantiva, portanto, quando predomina a lógica da adaptação ao invés da lógica de dominação da natureza presente na racionalidade instrumental-econômica. A racionalidade ambiental é, assim, uma racionalidade da sociedade que conhece e respeita a natureza, porque os membros dessa sociedade, os seres humanos - políticos e conscientes -, se reconhecem como parte integrante da natureza, que é vista não apenas como recursos naturais, mas como cenário co-evolutivo ${ }^{6}$.

A racionalidade ambiental, portanto, transita, ora na racionalidade substantiva, ora na racionalidade funcional-instrumental. É um "sistema de valores" de uma parte e um "sistema de normas, ações e relações de meios e fins" de outra. Nas palavras de Leff:

A racionalidade ambiental não pode ser definida tão somente em termos de sua racionalidade substantiva, mas se funda em princípios materiais e em processos produtivos que dão suporte aos valores qualitativos que orientam a reconstrução da realidade (LEFF, 2001, p. 132).

Com isto, Leff não afirma que vivemos já numa sociedade onde predomina a racionalidade ambiental, mas aponta elementos para demonstrar que a racionalidade ambiental ganha algum espaço na racionalidade social e produtiva a partir da inserção de novos critérios racionais encetados pela crise ambiental e pelo movimento ambientalista. Assim, como toda a corrente de autores críticos ao utilitarismo econômico, Leff aborda a racionalidade ambiental em termos de conteúdo, como crítica e alternativa à racionalização da sociedade moderna, a partir da mudança de critérios socialmente construídos, nos quais a preocupação com o meio ambiente torne-se inerente ao processo de desenvolvimento. Ele acredita que a construção da racionalidade ambiental vai se dando na medida em que a questão ambiental ganha espaço na consciência social e influencia a produção tecnológica e de conhecimento, assim como, as dinâmicas populacionais e produtivas. Ou seja, a construção de uma racionalidade ambiental como um processo de produção teórica (racionalidade teórica) e de transformação social, constrói-se pari passu ao desenvolvimento de um processo sociopolítico. Em suas palavras: "a construção desta racionalidade ambiental aparece como um processo de produção teórica, desenvolvimento tecnológico, mudanças institucionais e transformação social" (LEFF, 2001, p. 110).

Como produção teórica, mudança tecnológica e institucional entende-se a internalização não só de normas ecológicas e tecnológicas às teorias, mas também a incorporação dos aspectos socioambientais que contêm os conflitos sociais e políticos, e além da própria concepção de que sociedade e natureza não estão em universos diferentes, no sentido de construir um "desenvolvimento equitativo, sustentável e duradouro" (ver Sachs, 1986 e 1993). Ademais, a construção de uma racionalidade ambiental passa necessariamente pelo rompimento de barreiras epistemológicas e institucionais e pela criação de novos métodos de pesquisa e

${ }^{6}$ Ver: Davdson-Hunt, I.J. e Berkes, F. (2003) Nature and society through the lens of resilience: toward a human-in-ecosystem perspective. In: F. Berkes, J. Colding e C. Folke (Eds.) Navigating social-ecological systems. Building resilience for complexity and change. Cambridge: Cambridge University Press, p. 53-82. 
produção de conhecimento, no sentido de contemplar as transformações e necessidades sociais, políticas, econômicas e tecnológicas que a crise ambiental veio trazer.

A transformação social é entendida como aquela que se dá por meio de um processo sociopolítico, no qual são resgatados os princípios da racionalidade substantiva, e a partir dos quais são incorporados novos valores (ou resgatados antigos) no sentido de desfazer as duas inversões fundamentais que Ramos (1989) denominou de transavaliação social e da razão. Ou seja, por um lado, reverter a alienação do homem em relação ao seu meio e a si mesmo, resultante do processo de racionalização da vida, ocorrida no desenvolvimento capitalista e, por outro lado, desfazer a separação natureza e sociedade, promovida pelo Iluminismo e pelo paradigma ocidental de desenvolvimento, assim como as próprias desigualdades sociais maximizadas no modelo baseado numa economia de mercado.

A constituição de uma racionalidade ambiental, na medida em que integra processos de racionalidade substantiva e racionalidade instrumental, "passa por processos de desconstrução da racionalidade econômica dominante, bem como de transformação das instituições e dos aparelhos ideológicos que a sustentam e legitimam" (LEFF, 2001, p. 124). Passa também pela construção de um saber ambiental, "que emerge como uma consciência crítica e avança como um propósito estratégico, transformando os conceitos e métodos de uma constelação de disciplinas e construindo novos instrumentos para implementar projetos e programas de gestão ambiental" (LEFF, 2001, 126).

Leff absolutamente inaugura na discussão da problemática ambiental uma abordagem da racionalidade que até então era apenas citada de forma periférica tanto pelos autores do ambientalismo como pelos autores que debatem o enfoque da racionalidade. A crítica que recai sobre a sua formulação, entretanto, consiste no fato de que é expressa por meio de várias tipologias de racionalidade que apresentam definições pouco claras. A questão fundamental, porém, é que numa racionalidade ambiental, a internalização da dimensão ambiental nos processos de produção de conhecimento não deve seguir apenas a lógica instrumental da internalização das externalidades ambientais nos processos produtivos, (conforme propõe a economia neoclássica), mas também a lógica substantiva, como algo inerente. Leff afirma:

O saber ambiental, a partir de sua posição de externalidade ao desenvolvimento 'interno' das ciências, gera uma demanda de saber que repercute na orientação, desenvolvimento e aplicação dos conhecimentos. O propósito de internalizar a 'dimensão ambiental' na teoria e prática da economia exige a implementação de políticas científicas e tecnológicas para produzir instrumentos eficazes para refuncionalização ecológica da racionalidade econômica... (LEFF, 2001, p. 140).

A questão central a ser evidenciada, portanto, é que o problema da sociedade moderna consiste justamente na não submissão do processo de desenvolvimento ao julgamento da razão substantiva, senão apenas à razão funcional-instrumental, como único critério a ser ponderado (Ramos, 1989). A compreensão do agir comunicativo, como inerente à relação social, resulta da aplicação, em contextos de ação social, do modelo de racionalidade que emana dos processos de entendimento de validez criticáveis. A linguagem aparece com todo o seu potencial de motivar a convicção e de gerar consenso.

O agir estratégico, que resulta somente do modelo da racionalidade que emana dos processos de intervenção na natureza com o fim de uma manipulação com êxito, não passa de um meio de transmissão de informações e de influência de uns sobre os outros e sobre a situação da ação, induzindo o comportamento. Foi esse desequilíbrio, materializado pela sobreposição da economia formal sobre a economia substantiva que gerou a crise da razão e, consequentemente da sociedade moderna, cuja problemática socioambiental é um dos resultados mais expressivos. Portanto, cumpre resgatar nos processos sociais, produtivos e de produção de conhecimento, o julgamento da razão substantiva, cujos valores devem ser incluídos como critérios extremamente importantes à discussão socioambiental. 
A formulação de uma racionalidade ambiental consiste na identificação dos elementos substantivos e instrumentais que possam caracterizar a presença da dimensão ambiental como critério de racionalidade na sociedade. Ou seja, ela congrega tanto conteúdos substantivos, trazidos pela crise ambiental e pelo resgate do valor da natureza, como processos instrumentais vigentes na sociedade racionalizada. A atual problemática socioambiental é em si um forte argumento contra o modelo desenvolvimentista fundamentado na preponderância da economia formal, sendo também um apelo ao surgimento de uma sociedade regida pelo equilíbrio entre racionalidade instrumental e substantiva. Entretanto, justamente por esse ser um processo político, não se dará de uma hora para outra, nem sem o aproveitamento dos mecanismos existentes na sociedade racionalizada em termos funcionais e instrumentais. Esses mecanismos, que são o que Leff denomina de racionalidade técnica, devem ser utilizados a partir de sua submissão à racionalidade substantiva, no sentido de que a racionalidade ambiental não é apenas um aspecto da racionalidade substantiva, como um valor da natureza. Ela é o resultado da conjugação de duas racionalidades complementares, a racionalidade técnica, como uma racionalidade funcional-instrumental, e a racionalidade teórica, que vem sendo construída pelo movimento ambientalista como um todo e pela própria crise ambiental, que se materializa na forma de desequilíbrios ecológicos, desastres naturais, resultantes de impactos da ação antrópica, como uma racionalidade substantiva.

\section{Considerações finais}

A discussão que está posta nas proposições tanto de Habermas, Ramos, e Leff é a de que uma racionalidade mais substantiva, ambiental ou comunicativa depende do elemento da motivação da ação. É este o elo comum, ou seja, enquanto numa racionalidade instrumental o que está em jogo como critério de tomada de decisão e como motivação são a eficácia, o rendimento e o desempenho, na racionalidade substantiva são as obrigações éticas e moral, a partir das quais a conservação da natureza, por exemplo, tornam-se um valor intrínseco, na racionalidade comunicativa, segundo a proposta de Habermas, visa encontrar os fundamentos de uma teoria crítica da sociedade na linguagem, enquanto comunicação, isto é, enquanto mediadora das relações sociais. A partir de uma racionalidade substantiva, ambiental e comunicativa a conservação da natureza, assim como o pagamento dos impostos ou construção de uma casa, respeitando as diretrizes do plano diretor, são comportamentos valorativos, cuja recompensa é intrínseca e não só instrumental e funcional. O valor é o componente intrínseco da ação. Ou seja, a virtude é praticada por ter um valor intrínseco, não devido à conta custo/beneficio.

Da mesma forma quando se produz ou se adquire um produto ecologicamente correto, baseando-se numa racionalidade substantiva, ambiental e comunicativa, não se faz para otimizar uma relação meios/fins, mas para exprimir um valor, uma opção ética. Não se faz por causa de cálculos e resultados baseados em meios/fins, mas pela crença num estilo de vida e de economia motivado por preocupações coletivas que transcendem as vantagens econômicas individuais, baseadas na racionalidade instrumental, numa equação meios/fins, mas com base numa motivação sustentada por valores intrínsecos (éticos, morais, estéticos), cuja atitude é expressão destes valores e da noção de coletivo e cooperação.

A reflexão teórica de Guerreiro Ramos, Enrique Leff e Jürgen Habermas, apresentam como reconstrução teórica de condições e pressuposições que subjazem à convivência humana, no caso, a reconstrução teórica de condições e pressuposições que acompanham a linguagem e que explicitam um determinado modelo de racionalidade. Como reconstrução teórica, o artigo procurou tornar evidentes situações concretas do mundo vivido e não fundamentar-se com base em imagens-ideais de homem, ambiente e sociedade. Desvelar a racionalidade é condição necessária para que as pessoas possam cumprir suas tarefas concernentes à reprodução dos componentes do mundo da vida e ao mesmo tempo oferecer a possibilidade de uma perspectiva crítica capaz de identificar e de enfrentar as patologias do mundo atual, com ênfase para os parâmetros da razão comunicativa, conforme propõe Habermas. São estes parâmetros que devem controlar, em última instância, os processos sistêmicos, colocando-os a serviço das finalidades humanas 
comunicativamente estabelecidas. Por fim, cabe pontuar mais uma vez mais que, na análise das proposições destes três autores, o elemento comum e a discussão que emerge é que o tipo de racionalidade presente na ação social depende essencialmente da motivação da ação, o que necessariamente deve ser incorporado pela teoria organizacional.

\section{Referências}

ADORnO, T. W.; HORKHEIMER, M. Conceito de Iluminismo. São Paulo: Nova Cultural, 2000. Coleção os Pensadores.

ARISTOTELES. Política. Brasília: UnB, 1985.

FERNANDES, V. Racionalização da vida como processo histórico: crítica à racionalidade econômica e ao industrialismo. Cadernos da EBAPE.BR: São Paulo: FGV/EBAPE, 2008.

FREITAG, B. A Teoria Crítica Ontem e Hoje. 5. ed. São Paulo, SP: Ed Brasiliense, 1993.

GORZ, A. Metamorfoses do trabalho: crítica da razão econômica. São Paulo: Annablume, 2003.

HABERMAS, J. Legitmatins probleme in Spätkapitalismus. Frankfurt: Suhrkamp 1973 (cito trad. port. De Vamirech Chacon: A crise de legitimação no capitalismo tardio. Revista Tempo Brasileiro, Rio de Janeiro, 1980.

Theorie des kommunikativen Handelns. Frankfurt : Suhrkamp, 1981.

. Conhecimento e interesse. Rio de Janeiro : Guanabara, 1987.

. La lógica de las ciencias socialies. Madrid : Tecnos, 1988.

Law and Morality, in: the Tanner Lectures on Human Values. Cambridge : University Press, 217-279, 1988b.

. La lógica de la acción comunicativa: complementos y estudios previos. Madrid : Cátedra, 1989a.

Consciência moral e agir comunicativo. São Paulo: Brasiliense, 1989b.

O discurso filosófico da modernidade. Lisboa : Dom Quixote, 1990.

Pensamento pós-metafísico: estudos filosóficos. Rio de Janeiro: Revista Tempo Brasileiro, 1990a.

O discurso filosófico da modernidade. Lisboa : Dom Quixote, $1990 \mathrm{~b}$.

.Para a reconstrução do materialismo histórico. 2.ed. São Paulo: Brasiliense, 1990c.

Teoría de la acción comunicativa. Madrid : Taurus, 1992. Tomo I e II.

. Passado como futuro. Revista Tempo Brasileiro, Rio de Janeiro, 1993.

Teoría de la acción comunicativa: complementos y estudios previos. Madri: Cátedra/Teorema, 1994.

HOBBES, T. Leviatã ou matéria, forma e poder de um Estado eclisiástico e civil. São Paulo: Nova Cultural, 2000. Coleção os Pensadores.

HORKHEIMER, M. Eclipse da razão. São Paulo: Centauro, 2002.

HUME, D. Investigação acerca do entendimento humano. São Paulo: Nova Cultural, 2000. Coleção os Pensadores. 
ILLICH, I. A convivencialidade. Lisboa: Europa-América, 1976.

KANT, I. Crítica da razão pura. São Paulo: Nova Cultural, 2000. Coleção os Pensadores.

LEFF, E. Ecología y Capital. Racionalidad ambiental, democracia participativa y desarrollo sustentable. México/España: Siglo Veintiuno editores s. a. de C. V./Siglo Veintiuno de España editores s.a. 1986.

Sociologia y ambiente: sobre el concepto de racionalidad ambiental y las transformaciones de conocimiento. In: VIEIRA P. F. e MAIMON, D. (Orgs.). As ciências sociais e a questão ambiental: rumo à interdisciplinariedade. Rio de Janeiro/Belém: APED e UFPa, 1993.

Epistemologia Ambiental. São Paulo: Cortez, 2001.

LISBOA, A. M. A Crítica de Karl Polany à Utopia do Mercado. Lisboa: Instituto Superior de Economia e Gestão, Universidade Técnica de Lisboa. Centro de Investigação em Sociologia Econômica e das Organizações. Working Papers, 2000.

LOCKE, J. Ensaio acerca do entendimento humano. São Paulo: Nova Cultural, 2000. Coleção os Pensadores.

MANNHEIM, K. O homem e a sociedade: estudos sobre a estrutura social moderna. Rio de Janeiro: Zahar, 1962.

OLIVERIA, M. A. A filosofia na crise da modernidade. São Paulo : Loyola, 1989b.

POLANYI, K. El sustento del hombre. Barcelona: Mondadori, 1994.

. A grande transformação: as origens da nossa época. Rio de Janeiro: Editora Campus, 2000.

RAMOS, A. G. A nova ciência das organizações: uma reconceituação da riqueza das nações. Rio de Janeiro: Fundação Getulio Vargas, 1989.

Modelos de homem e teoria administrativa. Curitiba: PUC - Mestrado em Administração/Série Monográfica: Caderno de Ciências Sociais Aplicadas n³3, 2001. (Tradução Francisco G. Heidemann).

ROUANET, S. P. As razões do iluminismo. São Paulo: Companhia das Letras, 1997.

SACHS, I. Espaços, tempos e estratégias do desenvolvimento. São Paulo: Vértice, 1986.

1993.

Estratégias de transição para o século XXI: desenvolvimento e meio ambiente. Studio Bobel: FUNDAR,

SOUTO-MAIOR, J. Racionalidades: alguns esclarecimentos. Estudos Avançados em Administração: v.6, n.2, p.967991, 1998.

WEBER, M. A Ética Protestante e o Espírito do Capitalismo. São Paulo: Pioneira, 1996.

. Economia e sociedade: fundamentos da sociologia compreensiva. Vol. 1. Brasília: Unb, 1999. 